\title{
1型糖尿病患者のオーラルケア
}

サンスター株式会社オーラルケア事業本部製品開発部 野村 慶 雄

\section{Oral care for type 1 Diabetes Mellitus patients}

Oral Care Headquarter R\&D, SUNSTAR Inc. Yoshio Nomura

我が国における糖尿病患者梳、 1 型糖尿病患者と 2 型糖尿病患者を合わせて 218 万人である。平成 9 年に実施 された「糖尿病実態調査」による上、糖尿病が強く疑われる人は、690万人、これに糖尿病の可能性を否定でき ない人を合わせると 1,370 万人にも上っている。1 型糖尿病は、脺臟の $\beta$ 細胞の破壊を伴い、インスリン欠乏に より高血糖を主徵とする疾患である。1 型糖尿病は、全糖尿病患者の数\%（約 10 万人）で、0 18 歳までの小览 人口 10 万人当り $4 \sim 5$ 人と言われている。1 型糖尿病患者は、 1 日に $1 \sim 2$ 回血楉値を自己測定し、自ら $2 \sim 3$ 回 インスリンを注射しなければ血桾値を維持できない。

1 型糖尿病患者は、菌周病発症頻度が高く、アメリカの報告（P.A.Moore et al. J.Periodontol.1999）では、24 歳以下の患者では $4 \mathrm{~mm}$ 以上の歯周ポケットを有する割合が $12 \%$ であり、加齢とともに增加し、45 歳以上では 約 $60 \%$ の患者が $4 \mathrm{~mm}$ 以上の歯周ポケットを有している。また、プロービング時の出血はどの年齢においても約 $70 \%$ 見られる。NHANES III の調査結果では、桾尿病患者の約半数が歯周病に罹患している。このことを考え るならぱ、小児期に発症する 1 型糖尿病患者のオーラルケアを早期から実施することは、歯周病の発症を予防す る上で重要である。しかし、我が国においては、カリエス治療を受け入れる医療機関はあっても、歯周病治療あ るいはそのメインテナンスを受け入れる機関は必ずしも整備されているとは言えない。サンスター歯科保健振興 財団の附属千里歯科診療所は、大阪府・大阪市・堺市・兵庫県の小肾慢性特定疾患治燎研究事業の委託診療機関 として、1 型糖尿病患者とりわけ若年者の㐘周病治療ならびにメインテナンスを実施している。

我々は、全国の「つぼみの会」(1 型糖尿病患者の親睦団体) の 1 型糖尿病患者の歯周病治療ならびにオーラル ケアを受け入れる医療機関のネットワーク作りを提案している。1 型糖尿病患者は先に述べた㐘周病のリスクを 抱えているばかりでなく、低血糖対策としての補食で不定期に糖分を撕取寸ることから、カリエスのリスクも高 いと考えている。

本講演では、我が国における 1 型糖尿病患者、とりわ忖若年者の歯周病罹患状況と治療上の注意事項とともに、 1 型糖尿病患者が社会的汇置か水ている背景を確認することから、1 型糖沓病患者のオーラルケアの重要性を指 摘したい。加えて、全国の菌周病認定医の所属する医療機関が、1 型糖尿病患者の歯周病治療とオーラルケアの 受け入れ機関として、各自治体に申請し 1 型糖尿病患者のオーラルケアを受け入れることを提案したい。 